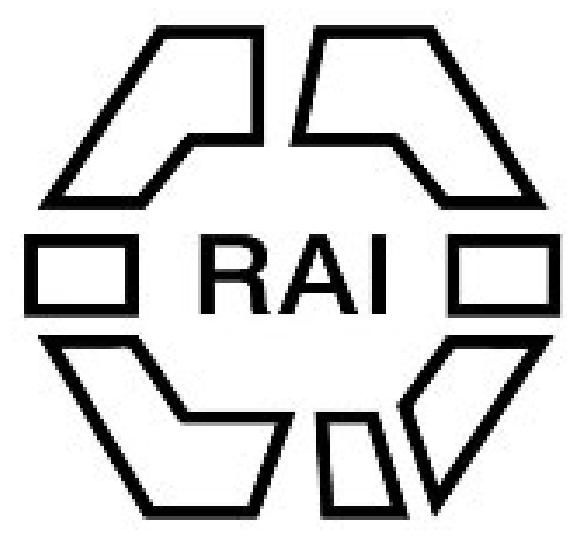

On the Game of Patolli in Ancient Mexico, and its Probably Asiatic Origin.

Author(s): E. B. Tylor

Source: The Journal of the Anthropological Institute of Great Britain and Ireland, Vol. 8 (1879), pp. 116-131

Published by: Royal Anthropological Institute of Great Britain and Ireland

Stable URL: http://www.jstor.org/stable/2841019

Accessed: 16/06/2014 00:26

Your use of the JSTOR archive indicates your acceptance of the Terms \& Conditions of Use, available at http://www.jstor.org/page/info/about/policies/terms.jsp

JSTOR is a not-for-profit service that helps scholars, researchers, and students discover, use, and build upon a wide range of content in a trusted digital archive. We use information technology and tools to increase productivity and facilitate new forms of scholarship. For more information about JSTOR, please contact support@jstor.org. 
of the unit, is based on that of Newton in his "Dissertation on Cubits," but makes an advance upon it by subjecting the probable errors of measurement, \&c., to calculation according to the theory of probabilities. Mr. Tylor hoped Mr. Petrie's results would be subjected to careful criticism, as if found correct they would afford great help in tracing the lines by which civilization has travelled. To students of barbaric culture, Mr. Petrie's attempt in his book to prove the existence among the mound-builders of North America of a unit closely approaching a measure used in the Old World deserved careful consideration. With reference to the elliptic enclosure described by Mr. Petrie, Mr. Tylor thought the evidence tending against the notion of its having been drawn with a line from two set foci, and that the elongation or diminishing of the ordinates of a smaller or larger circle was rather more likely.

\section{On the Game of Patolli in Ancient Mexico, and its Probably Asiatic Origin. By E. B. Tylor, Esq. D.C.L., F.R.S.}

THE group of games to which our backganmon belongs is ancient and widely spread over the world. In it a number of pieces are moved on a diagram or board, not at the player's free choice as in draughts or chess, but conformably to the throws of lots or dice. One can hardly doubt, from the peculiar combination of chance and skill here involved, that all the games coming under this definition must be sprung from one original game, though this cannot now be clearly identified, and may indeed have disappeared many ages since. The closeness of correspondence between the abacus or reckoning-board with its little stones or calculi moved on its lines or spaces, and the board and pieces for ancient backgammon, which were even called by the same names, strongly suggests the idea that the original backgammon arose out of the sportive use of the calculating-board. Its descendants, the backgammon family, fall into two groups of games: those played with numbered dice, and those played with two-faced lots which can only fall in two ways, as we say "head or tail." These two groups of games may be conveniently called dice-backgammon and lot-backgammon. Dice-backgammon makes its appearance plainly in classic history. The game of the "twelve lines" (duodecim scripta) was played throughout the Roman Empire, and passed on with little change through mediæval Europe, carrying its name of tabulae, tables; its modern representatives being French trictrac, English backgammon, \&c. Among ancient Greek games, the kubeia or "dice-playing" is shown by various classical passages to have been of the nature of backgammon. It appears from Plutarch that in early times 
it was played in Persia, where it still flourishes under the name of nard. There are also in Sanskrit literature mentions of related games in ancient India. For the purpose of the present paper, however, it will not be needful to go at length into the history of dice-backgammon. It is with the less familiar lotbackgammon that we are principally concerned. This, there is fair reason to believe, was the earlier, as it is the ruder form; dice-backgammon being a later improvement. That such is the case is made likely by the following descriptions of lotbackgammon, which show how clumsily the throwing of a whole handful of lots accomplishes what is done easily with one or two numbered dice.

One variety of lot-backgammon is to this day popular in Egypt and Palestine, under the name of tab or "game." It is described in Lane's Modern Egyptians, and in Hyde's De Ludis Orientalibus, part ii, p. 217. The lots thrown are tab-sticks, four slips of palm-branch about a span long, cut smooth on one side so as to be white, while the other side is left green, these sides being called the white and black respectively. The tabsticks are thrown against a wall or stick, and the throw counts according to how many white sides come uppermost, thus :-

Whites up, none, one, two, three, four,

$\begin{array}{lllllll}\text { Count } & 6 & 1 & 2 & 3 & 4\end{array}$

$$
\text { (go on) (go on,) (stop) (stop) (go on). }
$$

Here there is an evident attempt to fix the values of the throws according to the probability of their occurrence, though this is very crudely carried out. Not only do the rarer throws, of none-up and four-up score high, but they and one-up (tab) give the player a new throw, whereas the common throws of two-up and three-up lose the lead. This principle runs through all varieties of lot-backgammon. If, as is probable, such lotscoring represents the earlier form from which dice-scoring is derived, then the privilege of a new turn being given to the extreme throws is the origin of the same privilege being given to doubles in our backgammon. Next as to the tab-board. This is divided into four rows of squares, each row having $7,9,11$, 13 , or other odd number of squares or " houses," thus :-

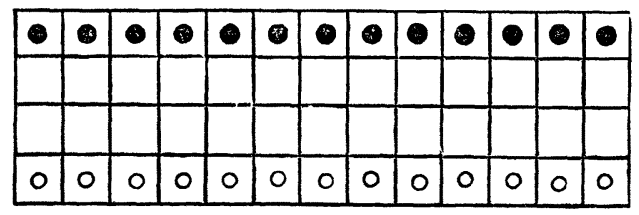

Rows of holes on a flat stone or on the ground will serve, and the pieces or " $\operatorname{dogs}$ " are bits of stone for one side and red brick 
for the other, the players starting by putting a piece in each square on his own side as shown in the figure. Now a " dog" or draught can only be moved from its original square by a throw of tab (one-up). While still inert in its original place the draught is called a Nasara or Christian, but by the throw of tab it is made a Moslem, and can go out to fight. Suppose a player at the beginning throws tab, then four, and then two, he uses the first to bring forward his right-hand draught to the square in front, then moves it on six squares to the left, and then, his last throw having lost the lead, the other player takes his turn. When a throw enables a draught to be moved to a square occupied by one of the enemy's draughts, this is taken, but a square occupied by several draughts is safe. That is to say, our familiar rule of taking a man or hitting a blot belongs to lotbackgammon. The game is ended by one player losing all his men. It remains to be pointed out that the lot-throwing part of the game is sometimes played by itself. The player who throws four is called Sultun, and he who throws six receives the title of Wezir, while the unlucky thrower of two or three gets blows on the soles of his feet.

We now turn to the kind of lot-backgammon played in India, and now generally known under the name of pachisi. It is a popular mode of gambling in India, and even Europeans have been known to catch the enthusiasm of the natives, as witness the well-known story of that English official who, having paid his servants' wages, would sit down with them to a match at pachisi and sometimes win his money back. At the time of reading this paper, the best account of the game accessible to me was that in Herklot's Qanoon-e-Islam, but Mr. Arthur Grote has since kindly procured, through Dr. Rajendralala Mitra, of the Calcutta University, a more complete and consistent set of rules, which are here followed. The game may be played by two, three, or four persons severally, or by two pairs, the partners sitting opposite one another. A cloth, with coloured patches on it, to form the pattern or diagram, is generally used as a board, zealous players often carrying one rolled round in their turbans. The diagram or board is as shown in the illustration.

Each of the four arms contains 24 squares, of which the three crossed squares are called forts (chik). The pieces played with (got) are usually of turned wood or ivory, of a conoidal shape, much like our present rifle-bullets, and in sets of four, each of the four players having a set all of one colour, red, green, yellow, black. The moves of the pieces on the board are determined by the throws of cowrie-shells, which count according to how many fall mouth upward. The scoring is as follows when six cowries are used :- 
Mouths up, none, one, two, three, four, five, six. Count,

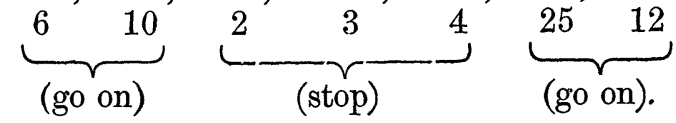

Suppose now four players to be seated, each at the end of one cross-arm. The object of each player is to move his men

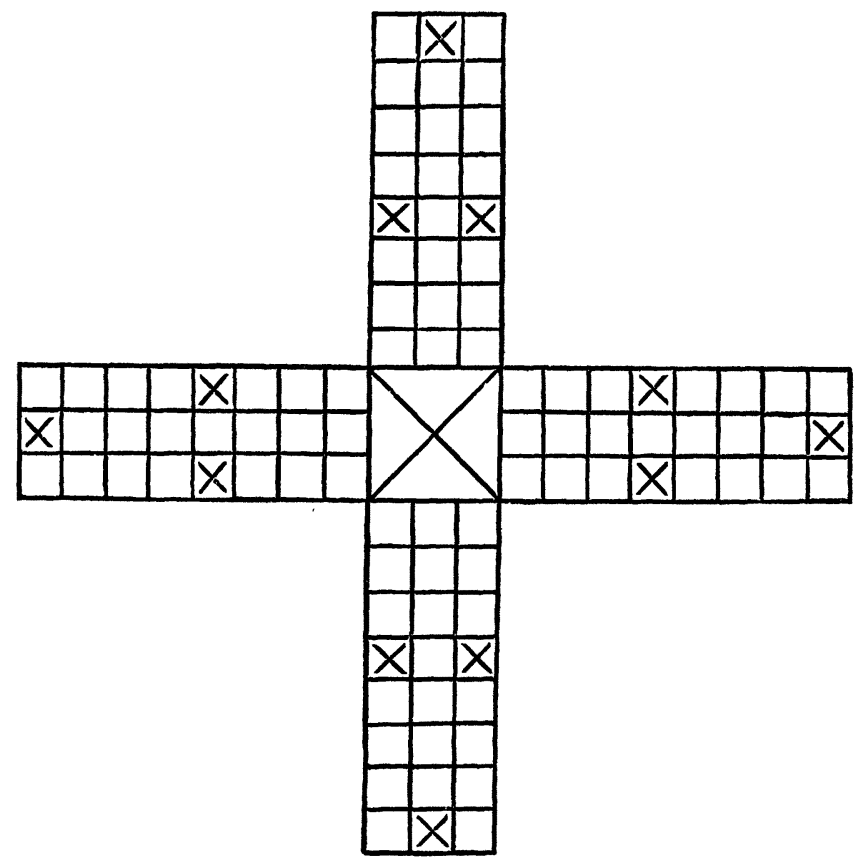

from home down the middle row of his own arm, and then along the outside lines of squares from right to left (against the sun) till having made the circuit of the whole board, they come back to the end of their own arm, move up its middle row where they came down, and get back into the central space or home, the winner being he who gets his four men round first. The pieces move onward as many squares as the score of the throw. But a piece can only be started in the game when its owner throws a 10 (das) or a 25 (pachisi), which throws give a starting 1 (puá) in addition to the ordinary score, by which 1 a-piece is put on the first square and so started on its course. The high throws $6,10,12,25$, entitle the player to a new throw as doublets do in our backgammon, but at the lower throws the lead passes to the other player. Thus when the game begins, the throws are 
useless till one player throws 10 or 25 ; suppose he throws 10 , and this giving him a new throw, afterwards 2 , he is able to start a piece on the first square, and then move it 10 and 2 squares onward. A single man on a square is taken by an enemy's man moving on to that square, and the taken man being dead (mará) is put back in the home to start afresh, but two or more men of one set on a square hold it safely, all which is as in our backgammon. In pachisi, however, taking or cutting (kátá) a man gives the player a new throw. Also in pachisi, the crossed squares or forts are places where a single man is in safety, and even blocks an enemy's man from moving there. The throws just mentioned, 10 followed by 2 , are favourable as entering a man and putting him in safety in a fort; a 25 followed by a 4 is good in the same way. When a piece, after making the circuit of the board, comes back to go up its own middle row, it is called ripe (pakka) and is laid on its side to distinguish it from the starting-pieces on their way down. If the ripe piece gets again on the last square before home, it can only be got off the board as it got on, by a throw of das or pachisi.*

The comparison of this Hindu game of pachisi shows close connection with the Arab tab; we have even the privileged throws giving a new throw, and a particular throw required to start a man. In India there is also played another game like pachisi except that the cowries are superseded by a kind of long dice, numbered on the four long sides but not at the ends; as thus played the game is called chîpur. The pachisi board has been introduced into England, with four sets of four small draughts as the pieces, and ordinary dice. In this state the game has made its nearest approach to our backgammon, and any one who tries the set of games will be likely to admit that in the pachisi played with cowries as lots, he has before him an early and rude stage of the game as lot-backgammon, out of which it passed into dice-backgammon. He may also be

* Further details. If 25,10 , or 12 are thrown thrice running, they are called rotten (pachá) and destroy one another, but a new throw of 10 or 25 may restore them, and so with six consecutive throws, restored by a seventh. In going home up the middle row, a player cannot use a throw for which there are not sufficient squares left. When players are in partnership, their pieces can be in the same squares. A partner whose pieces are all home can throw on his partner's behalf, a ̈rter getting a new starting 1 . He may also make a ripe man on its way home into an unripe one, for the purpose of cutting off an enemy's man, or revive and bring out again a piece which has got home. Sometimes a player having two pieces on one square moves them as a couple (jora) which can take an enemy's couple. Such couples can move at option to the 12th or 25th square with a throw of 25 or to the 5th or 10th square with a throw of 10 , but uneven throws other than 25 disjoin the couple. This system of couples (which is allied to the plan of joining pieces in the Arab tab) is said not to be recognized by good pachisi players. 
disposed to think that our own dice-backgammon, though tolerably ancient, came into existence by a similar course of development. It should be added that both as played with cowries and dice, games like pachisi are ancient in India. Having looked into the Sanskrit references and consulted Professor Jolly, of Würzburg, I am inclined to think that a game called panchikd, played with five cowries, may represent one of its earliest forms, for the name of pachisi, meaning " fiveand-twenty," is clearly derived from the scoring of the throw of five cowries. Leaving this for further examination, it will be sufficient to have given an idea of the nature of the Hindu pachisi, for it is to this game that a variety of lot-backgammon appearing in Old Mexico will now be seen to present the most striking analogy.

Among the accounts of this Mexican game given by the Spanish chroniclers the earliest is that by Gomara, whose history was printed in 1552, so that his account must have been written while the conquest in 1521 was still fresh in memory. He writes as follows: "Sometimes Montezuma looked on as they played at patoliztli, which much resembles the game of tables and is played with beans marked like one-faced dice, which (beans) they call patolli, which they take between the hands and throw on a mat, or on the ground, where there are certain lines like a merrel (or draught) board, on which they mark with stones the point which fell up, taking off or putting on a little stone.* Torquemada, partly following this account, gives more details, showing the diagram played on to have been of the shape of a pachisi board, and the players to have had men of different colours. He says that "they call it the game of patolli, because these dice are called so; they throw them with both hands on a thin mat . . . . on which are made certain lines after the manner of a + cross and others crossing them marking the point falling up (as at dice) taking off or putting on little stones of different colour, as in the game of tables." $\dagger$

* Francisco Lopez de Gomara, "La istoria de las Indias, y conyuista de Mexico" [Saragossa] 1552, fol. 42. "Algunas vezes mirauia Moteç̧̧uma como jugauan al Patoliztli, que parece mucho al juego de las tablas. Y que se juega con hauas, o frisoles raiados como dados de harinillas que dizen Patolli. Los quales menean entre ambas manos. Y los echan sobre una estera, o en el suelo, donde ay ciertas raias, como alquerque, en que señalan con piedras el punto que cayo arriba, quitando, o poniendo china "

† Juan de Torquemada, Monarquia Indiana, Seville 1615, Book xiv., c. 12. "Auia otro juego que llaman Patolli, que en algo parece al juego de las tablas reales, y juegase con hauas y frisoles, hechos puntos en ellos, a manera de dados de arenillas, y dizenle juego Patolli, porque estos dados se llaman assi ; echanlos con ambas manos sobre una estera delgada que se llama petate, hechas ciertas rayas a manera de aspa y atrauessando otras señalando el punto que cayò hazia arriba (como se haze en los dados) quitando, o poniendo chinas de diferente color, como en el juego de las tablas." The word "aspa" means an equal-armed cross, the

VOI. VIII. 
Next come the particulars given by Sahagun, which though not adding much to our knowledge of the game, explain why it ceased to be played some time after the conquest. "The lords for their pastime also played a game called patolli, which is as the game of merells (or draughts) or the like, or dice-playing, and there are four large beans, each having a hole, and they throw them with the hand, as one plays at knuckle-bones, on a mat where there is a figure drawn. At this game they used to play and win precious things, such as gold beads and precious stones, very fine turquoises. This game and that of ball they have left off, being suspicious on account of some idolatrous superstitions in them." In another place he says: "The second pastime they had was a game like dice; they made on a mat a painted cross, full of squares like the game of draughts, and sitting down on the mat, they took three large beans with certain points made in them, and let them fall on the painted cross, \&c.*

At the reading. of my paper, I was only able to refer to the work of Diego Duran as cited in Bancroft's Native States of the Pacific, vol. ii, p. 300. The part of his work containing the account of patolli is still in MS., but there is a transcript in the Bancroft Library at San Francisco, from which Mr. Oak, the librarian, has since kindly furnished me with an extract. The game they played on the mat (says Duran) they called patolly, which is the same name we now give to cards. On this mat they had a great cross painted taking the mat from corner to corner. Within the hollow of the cross were certain transverse lines forming houses or squares, which cross and squares were marked and drawn in lines with liquid ulli (indiarubber). For these squares there were twelve small stones, six red and six blue, which they divided between the players, to each so many. If two played, which was the ordinary way, one took six and the other the other six. The dice were certain black beans, five or ten

arms of a windmill, \&c.; " arenillas" are dice with points only on one face or side, they are numbered from one to six.

* Fr. Bernardino de Sahagun, "Historia Universal de las Cosas de Nueva España," printed in Lord Kingsborough's "Antiquities of Mexico," vol. vii., book viii., c. 10. "Tambien los Señores por su pasatiempo jugaban un juego que se llama Patolli, que es como el juego del castro ó alquerque ó casi, ó como el juego de los dados; y son quatro frisoles grandes que cada uno tiene un agujero, y arrojanlos con la mano, sobre un petate como quien juega a los carnicoles donde está hecha una figura. A este juego solian jugar y ganarse cosas preciosas, como cuentas de oro y piedras preciosas, turquesas muy finas. Este juego y el de la pelota hanlo dejado, por ser sospechosos de algunas superstitiones idolatricas que en ellos hay," c. 17. " $\mathrm{El}$ segundo pasatiempo que tenian era un juego como dados; hacien en un petate una cruz pintada, llena de cuadros semejantes al juego del alquerque o castro, y puestos sobre el petate sentados, tomaban tres frisoles grandes, hechos ciertos puntos en ellos, y dejabanlos caer sobre la cruz pintada, y de alli tenian su juego ;" \&c. 
or as they chose to lose or gain, which had certain white holes in each bean where they marked the number of squares which were gained on each hand; where five were marked they were ten, and ten twenty; and if one, one; and if two, two; and if three, three; and if four, four; but marking five they were ten, and if ten, twenty; and so those little white dots were lots and markers of the lines that were gained, and for shifting the stones from square to square. Duran goes on to describe (as the other authors do) the eagerness with which the Mexicans played at this game; how gamesters went about with the mat and stones in a little basket under their arms; how they spoke to them as though they were things with sense and intelligence; and having talked to them with a thousand loving words and requests, would set up the little baskets with the instruments of the game and the painted mat, and bringing fire would throw into it incense and sacrifice before those instruments, bringing offerings of food. Having finished the offering and ceremonies they went off to play with all the confidence in the world. The author continues, that the name of the god of the dice was Macuilxochitl, which means Five roses (five flowers would have been more correct). Him the players invoked as they threw the beans from the hand, which was in the following manner: That the beans serving as dice are five in honour of that god named Five Roses, and to throw the lot they keep rubbing them a while between their hands, and on throwing them on the mat where there is the figure of the fortune and its counting which is in the manner of two clubs, they called with a loud voice on Macuilxochitl and gave a great clap, and then looked to see the points that had come, and this Macuilxochitl was only for this game of the dice. It seems, however, that they would also sometimes call on the god of gambling, Ometochtli, to give them a good point, \&c.*

* Diego Duran, "Hist. Indias," MS., tom. iii., cap. xxii. . . . . . al juego que sobre esta estera jugaban llamaban "patolly," que es el mismo vocablo que ahora llamamos naypes. Sobre esta estera tenian pintada una aspa grande la que tomaba el petate de esquina á esquina. Dentro del hueco de la aspa habia atravesadas unas rayas que servian de casas, la cual aspa y casas estaban señaladas y rayadas con ulli derretido . . . . para estas casas habia doce piedras pequeñas las seis coloradas y las seis azules, las cuales pedrezuelas partian entre los que jugaban á tantas á cada cual : si jugaban dos que era lo ordinario tomaba el uno las seis y el otro las otras seis ; y aunque jugaban muchos jugaba uno por todos ateniendose á la suerte de aquel, como entre los Españoles se juegan los albures ateniendose á la mejor suerte, así se atenian acá al que mejor meneaba los dados, los cuales eran unos frisoles negros cinco ó diez ó como querian perder ó ganar, los cuales tenian unos ahugerillos (sic) blancos en cada frisol por donde pintaban el numero de las casas que se aventajaban en cada mano, donde se pintaban cinco eran diez y diez veinte, y si uno, uno, y si dos, dos, y si tres, tres, y si cuatro, cuatro ; pero pintando cinco eran diez, y si diez veinte, y así aquellas pintillas blancas eran suertes y cuenta de las rayas que se ganaban; y darmua pars la 
These accounts of patolli are the only ones to be trusted, the newer ones being hardly to the point, except where they are following the old authorities. Clavigero repeats what he has read, adding that "he who first got three stones in a row, won." * But this may only be an amplification of his predecessors' comparison of the game to alquerque, which seems to have been like our merells, where counters are moved on a diagram with the object of getting three in a line, whence it is also called in Spanish "tres en raya," or "three in a row." Again, Brasseur says that he who returned first into the squares won the game. $\uparrow$ Probably it was so, but this author in stating it may only have gone upon the earlier statement that the game was played like tables.

Putting all this together, it is plain that the Spanish chroniclers were right in comparing patolli to their own game of tables or backgammon, but had they been acquainted with pachisi, they would doubtless have pointed out the closer connection of patolli with this Indian game. The playing backgammon-fashion with coloured stones as counters, on a diagram like a cross, full of squares, on which the moves were made by counting squares according to the throws of marked lots, in scoring which a disproportionate advantage was given to the high throws, all corresponds to pachisi. And where the beans

piedras de unas casas en otras . . Andaban los taures de este juego siempre con la estera debajo del sobaco, y con los dados atados á un pañito como algunos taures de este tiempo, que siempre andan apercibidos con los naypes en las calzas de tablage en tablage; aquellos dados juntam te con las piedrezuelas del juego traian en una bascrita (sic) pequeña á los cuales hacian reverencia como á Dioses fingiendo en ellos haber alguna virtud, y asi les hablaban cuando jugaban como á cosa que tubiese algun sentido ó inteligencia de lo que le pedian . . . . asi estos naturales hablaban á los frisolillos y al petate y decian mil palabras de amor y mil requiebros y mil superstiticiones, y despues de haberles hablado ponian las petaquillas en el lugar de adoracion con los instrumentos del juego y la estera pintada junto á ella y traia lumbre y echaba en la lumbre incienso y ofrecia su sacrificio ante aquellos instrumentos ofreciendo comida delante de ellos. Acabada la ofrenda y ceremonias ivan á jugar con toda la confianza del mundo."

"El nombre del Dios de los dados era Macuilxuchitl, que guiere decir cinco rosas : á este invocaban los jugadores cuando arrojaban los frisoles de la mano, Jo cual era á la manera que dire; que los frisolillos que sirven como de dados son cinco á honra de aquel Dios que tiene nombre de cinco rosas; y para echar la suerte traenlos un rato refregándolos entre las manos, y al lanzallos sobre la estera donde está la figura de la fortuna y cuenta suya que es á la manera de dos bastos, llamaban á alta voz á Macuilxuchitl, y daban una gran palmada, y luego acudia á ver los puntos que le habian entrado; y este Macuilxuchitl era solamente para este huego de los dados."

“. . . invocaban á este Dios cuando jugaban, diciendo 'el Dios Ometochtly me de buen punto," \& \&.

* Clavigero, "Storia Antica del Messico," Cesena, 1780, vol. ii., p. 185, “e chi prima aveva tre pietruzze in fila, quegli vinceva."

† Brasseur de Bourbourg, "Histoire des Nations Civilisées du Mexique et de l'Amérique Centrale," Paris, 1858, vol. iii., p. 671, "et celui qui retournait le premier dans les cases gagnait la partie." 
used as lots at patolli seem to have been sometimes only marked on one side to distinguish them from the other in head-and-tail fashion, while sometimes they were numbered; this matches with the two ways of playing the Hindu game, with cowries as two-faced lots, or with the numbered stick-dice. It seems so clear that the Mexican game must have come from Asia, that the question first arises-Could any Spanish or Portuguese sailor have learnt it in the East Indies, and then on a voyage to the West Indies have been, perhaps, wrecked on the Mexican coast, and taught his new acquisition to the natives? But the dates do not allow room for this supposition.

Vasco de Gama's voyage to India was about 1500 , and the conquest of Mexico was in 1521. It is by earlier direct communication from Asia that we must explain the presence of patolli in Mexico. That such communication took place has been proved by Alexander von Humboldt's well-known argument from the occurrence in Mexico of a chronological calendar in which signs were combined to date days, years, \&c., on a complex perverse principle closely resembling that on which the Tibetans, Chinese, \&c., still reckon dates. Not only were the signs, tiger, dog, ape, hare, \&c., used to date periods of time both by these nations and the ancient Mexicans, but they combine such signs in series, so that as in Japan "younger Fire Hare" denotes the fourth year of the cycle, so in Mexico "two Hare Fire" stands for the 28th day of a year. The correspondence between the myths of successive destructions of the world in Asia and Mexico is hardly less remarkable. The same causes which brought Asiatic calendars and myths into Aztec culture, may have brought over the Indian game of pachisi. It is not needful to account for this connection between nations of the two continents by supposing migrations of population on a large scale. The necessary contact might even have been made by the drifting over of boats or junks, with the crews alive, from East Asia to the Pacific coast of North America: an event which happens every now and then, as it probably has done for ages. By whatever communication Asiatic calendars and cosmic myths found their way into America, the Hindu game of pachisi or some allied form of it may have passed over from somewhere in Asia, and established itself in Mexico as patolli.

The evidence derived from this game, however, by no means ends here. Father Joseph Ochs, a Jesuit missionary who was in Mexico in 1754-68, in the following passage is no doubt speaking of the natives in the Tarahumara and Pima district. "Instead of our cards they have slips of reed or bits of wood, a thumb wide and almost a span long, on which, as on a tally, different strokes are cut in and stained black. These they hold 
together tight in the hand, raise them as high as they can, and let them fall on the ground. Whoever then has most strokes or eyes for him, wins the stakes. This game is as bad as the notorious hazard. They call it patole. As it is forbidden under pain of blows, they choose a place out in the woods, yet the noise of these bits of wood has discovered me many sharpers hidden in the bush. To play the more safely they spread out a cloak or carpet, not to be betrayed by the noise."* Thus toward a thousand miles from the city of Mexico, we find a game going on which still keeps the Aztec name of patolli, although the language of the district is not Aztec, and which seems to be the Mexican game so far as the casting lots are concerned, but without the counters. The use of slips of wood as lots is curiously like the Egyptian tâb, which game also, it was noticed, is sometimes played without the counters, though only for sport, not gambling.

If now we travel another thousand miles and more northeastward, into the region of the great lakes, we shall find among the so-called North American Indians a game which on examination appears closely connected with the Mexican patolli. It is widely spread, and has been mentioned by many authors as the game of plum-stones, game of the bowl, \&c. It was clearly not derived from the Europeans, and is noticed as a regular Indian game by the Jesuit missionaries among the Hurons as early as 1636 ; $\dagger$ they call it jeu de plat, and say it was played with six plum-stones, white on one side and black on the other, in a dish which was hit hard against the ground so that the stones turned over anyhow, the game being to get them all black or all white. They clearly did not quite understand the game, of which the best account is that given by Mr. L. H. Morgan, as played among the Iroquois.f It appears in two forms. As gus-ga-e-sá-tä, or deer buttons, it was strictly a fireside game,

* Murr, "Nachrichten von verschiedenen Ländern des Spanischen Amerika," Halle, 1809, part i., p. 256. " Anstatt unserer Karten haben sie daumenbreite, fast spannenlange Rohrschnitze, oder auch Hölzergen, in welche, wie auf einem Kerbholze, verschiedene Striche eingeschnitten und schwarz getränkt sind. Diese halten sie in der Hand fest zusammen, heben sie so hoch sie können in die Höhe, und lassen sie auf die Erde fallen. Wer denn mehrere Striche oder Augen über sich hat, gewinnt den Einsatz. Dies Spiel ist so schlimm, als das verruchte Würfelspiel. Sie nennen es Patole. Weil es bey Strafe der Schläge verboten ist so ersehen sie sich hiezu einen Ort im Gebüsche aus ; jedoch hat mir der Klang dieser Hölzerchen manche im Gebüsche versteckte Gauner entdeckt. Sicherer zu spielen breiteten sie einen Mantel oder Teppich aus, um nicht durch den Schall verrathen zu werden," \&c.

† "Relations des Jesuites dans la Nouvelle France" (reprinted Quebec, 1858), 1636, p. 113. See also Loskiel "History of Mission of United Brethren among the Indians in North America," translated by Latrobe, London 1794, part i., p. 106.

士 L. H. Morgan, "League of the Iroquois," Rochester (N.Y.), 1851, p. 302-307. 
though sometimes introduced as an amusement at the season of religious councils, the people dividing into tribes as usual and betting upon the result. Eight buttons, about an inch in diameter, shaped like a double-convex lens, were made of elkhorn, rounded and polished, and slightly burned on one side to blacken them. The game was played by two or more, all the players continuing in their seats till it was determined. A certain number of beans, fifty perhaps, were made the capital, and the game continued until one of the players had won them all. Two persons spread a blanket, and seated themselves upon it. One of them shook the deer buttons in his hands, and then threw them down. If 6 turned up of the same colour, it counted 2 , if 7 , it counted 4 , and if all, it counted 20 , the winner taking as many beans from the general stock as he made points by the throw. He also continued to throw as long as he continued to win. When less than 6 came up, either black or white, it counted nothing, and the throw passed to the other player. In this manner the game was continued until the beans were taken up between the two players. After that the one paid to the other out of his own winnings, the game ending as soon as either player's beans were all lost. Or four could play, either with a partner or independently. When deer buttons was played as a public game, the arrangement was as in the peach-stone game.

The peach-stone game, gus-kë-eh, was a betting game, played by the people divided into tribes, and by custom it was the concluding exercise on the last day of the Green Corn and Harvest Festivals, and also of the New Year's Jubilee. Its introduction among them is ascribed to the first $T o-d o-d \ddot{a}-h o$, who flourished at the formation of the "League," and a popular belief prevailed that it would be enjoyed by them in the future life, in the realm of the Great Spirit. It was played in the public council-house, by a succession of players, two at a time, under the supervision of managers. A number of beans, usually 100, made the bank. When the bets had been made, and the articles staked delivered into the custody of the managers, these seated thesnselves on a raised platform, the throng arranged themselves in two divisions, and two players sat down to play, one on each side, each provided by the managers on his own side with five beans out of the bank. Six peach-stones were used, ground or cut down to the flattened roundish form required, and burnt on one side to blacken them. They were put in a wooden or earthen bowl and shaken by the player. When they ceased rolling, if all came up of one colour, white or black, it counted 5, entitling the player to receive 5 beans from his adversary; if 5 came up of one colour, it counted 1 , giving 1 bean; if less than 5 of either 
colour came up, it counted nothing, and the lead passed to the opponent. When either player had lost all his stock of beans, he retired, and a new player with a new stock replaced him, till one side had gained all the beans, thus winning the game.

This using of beans as counters may possibly have been learnt by the Indians from the white men, so that we must not found any ethnological argument on it, nor can we with safety treat as properly belonging to the Indian tribes of America the varieties of the game which are described in Schoolcraft's "Indian Tribes," Part II., p. 71, as played by the Dacotas under the name of kun-ta-soo, and by the Ojibwas as puggesaing. The Dakota game is played with eight plum-stones, but some of them are marked with figures of tortoise, war-eagle, \&c., and the counting is elaborate. The Ojibwa name is well known to English readers from Longfellow having embodied in his "Hiawatha" a long description of it from Schoolcraft, under the title of "the game of bowl and counters, puggesaing with thirteen pieces." It has in it brass discs and pieces of bone cut to represent ducks, war-clubs, \&c, and these all have a right and wrong side, the reckoning of the combinations thrown ranging from nothing up to 158 for a single throw, in a most complicated way. Now though modern Indians have played these games, there are no early mentions of them, as there is of the simple game of the bowl and plumstones. It is therefore quite likely that these more complex games may be modern varieties of the old American game of the bowl, made with European help.

To sum up the argument from the presence of these games in America. Lot-backgammon as represented by tab, pachisi, \&c., ranges in the Old World from Egypt across Southern Asia to Birma. As the patolli of the Mexicans is a variety of lotbackgammon most nearly approaching the Hindu pachisi, and perhaps like it passing into the stage of dice-backgammon, its presence seems to prove that it had made its way across from Asia. How it came is uncertain, though the drifting across of Asiatic vessels to California offers the readiest solution. At any rate, it may be reckoned among elements of Asiatic culture traceable in the old Mexican civilization, the high development of which in metal work, architecture, astronomy, political and religious institutions, \&c., seems to be in large measure due to Asiatic influence. From Mexico, it appears that gambling by means of lots spread among the ruder north-west tribes, bearing the Aztec name of patolli, and being in fact the lot-casting part of that game but without the board and stone counters. Moreover, similar gambling by lot-casting was early found among the tribes of the great American lakes. This method of lot-casting, which corresponds to that of lot-backgammon, was certainly not 
introduced into America by the Europeans, who were not acquainted with it. We are therefore left to consider that the North American Indians got it probably through Mexico, but at any rate in some manner from Asia. Now if any item of culture, even a matter so trifling as a game, can be distinctly made out to have passed over from Asia and established itself among the rude tribes of North America, this opens a way by which various other features of their culture may be fairly accounted for as due to Asiatic influence.

\section{Discussion.}

Lieut. Col. Godwin Austen said: I have listened with very great interest to Mr. Tylor's paper on the striking similarity of the old Mexican game of "patolli" with the common Indian game called "pachisi." I became acquainted with this last when employed on the survey of Kashmir some years ago. It was the favourite game of the natives of my establishment, and this led me to learn the game, which I often played with them, and I became then well acquainted with the rules. Knowing that Mr. Tylor was writing on the subject, I have put a few notes and the rules together of the game as played by the Kashmiris, Punjabis, \&c.

The game is well known all along the northern part of India to Assam. I do not know whether it extends to Burma, but very probably is known there, from the larger Hindustani element now in the country. I can, I think, clear ap the meaning and similarity of one of the statements regarding the Mexican game so described by the old Historian (Clavigero) who very probably did not thoroughly know the game of patolli, and described it as a lookeron would do, and as most Europeans in India would now if explaining the game of pachisi $\mathrm{He}$ says the game ends when three of the coloured pieces are all in a row. Now in the game of pachisi, played with four sets of three-coloured markers, "Gúti", as they are played out they are placed in a row within the centre square or goal, and opposite to the player's own arm of the cross-board, and this position shows plainly to those engaged how many each individual has played out round the table; the first to place them all in a row being the winner, the others in succession.

\section{Rules of the Game of Pachisi.}

The game is played by two, three, or four persons (A B C D) having three markers (Gúti) or counters of different colours each (to shorten the game only two are often agreed on to be played), these are moved over the squares of the board, commencing at $A$ to $a^{\prime}$, $\mathrm{a}^{\prime \prime}, \mathrm{a}^{\prime \prime \prime}, \& \mathrm{c}$. Certain squares are marked with diagonal lines; in these a marker is safe and cannot be taken up; the term for this is "Gríché baithna,"-Gúché being probably a corruption of Gosha, used in the sense of "Gosha Nishin"-a hermit. 
2. The moves are regulated by the throw of seven cowries in different combinations.

A cowrie falling with the aperture uppermost is called "chit," with the aperture down or flat, "put."

The highest throw, "pachis," gives the name to the game -is

Six cowries with aperture up, one down-

The next highest all seven cowries with aperture upwards

All seven with aperture down

All down and one up

All down and two up

All down and three up

and so on up to five.

$$
\begin{array}{rr}
= & 12 \\
= & 6 \\
= & 1 \\
= & 2 \\
= & 3
\end{array}
$$

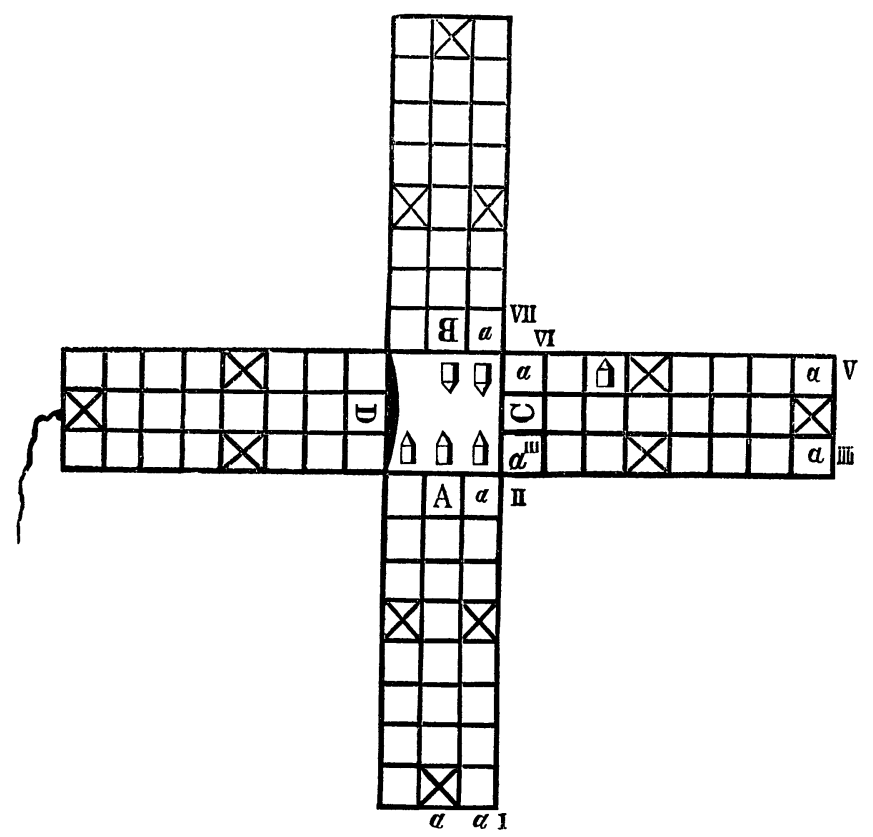

The Board is made of Cloth, with a pocket at $D$ to hold the markers. It then foles up and is tied by a string. The markers are made of wood coloured with lac worked in on a lathe.

3. A throw of twenty-five, twelve, or six must be made to enable a player to come in. Place the first marker on the board and commence play, and so for each marker, this is called pauwa-or getting an ace; a throw of the above numbers gives an extra throw.

4. On playing out, should the marker get into the last square a throw of twenty-five, twelve, or six must be made to take it off the board. 
5. Markers are taken up "guti marna." when by the throw of the cowries a marker can be placed in a square already occupied by an adversary-who then has to commence again from his original side of the board.

It will be seen from the construction of the board that from one corner square to the opposite and inner corner square is 25 , or from $a^{\prime}$ a i. to a'" a vii.

Mr. Hyde Clarke suggested to Mr. Tylor that the Tarahumara language possesses elements independent of its Aztek affinities, and that, too, it is related to remarkable languages of the Old World. He considered the discovery of Mr. Tylor's had another important link in the connection between the Old World and the New, and could not concur with him in attributing the calendar, the creation legend and the attoli, and he would add the measurements of Mr. Petrie, and so many other proofs of connection, to the casual influence of Chinese and Japanese wrecks before the time of Monteruma. He attributed them to specific migration, of which they had now so much evidence.

Mr. Walhouse, Capt. Dillon, and the President took part in the above discussion, and Mr. TyLOR replied.

APRIL 30TH, 1878.

Major-General A. LANe Fox, F.R.S., Vice-President, in the Chair.

The minutes of the previous meeting were read and confirmed.

The following presents were announced, and thanks were ordered to be returned to the respective donors for the same.

\section{FOR THE LiBRARY.}

From the SocIETY.-Proceedings of the Royal Society. Vol. XXVII, No. 186.

From the Societr.-Mémoires de la Société Impériale des Amis d'histoire naturelle, d'Anthropologie et d'Ethnographie. Vol. XXIX.

From the Sociery.-Bulletin de la Société d'Anthropologie de Paris. Tome XII, No. 4. 